\title{
Bilateral non-tender parotidomegaly: a clue for underlying HIV infection and lymphocytic interstitial pneumonia
}

\author{
Deepanjan Bhattacharya, Pandiarajan Vignesh, Nameirakpam Johnson, Pratap Patra
}

Pediatrics, Post Graduate Institute of Medical Education and Research, Chandigarh, India

\section{Correspondence to} Dr Pandiarajan Vignesh, vigimmc@gmail.com

Accepted 19 April 2019

\section{DESCRIPTION}

A 2-year-old boy presented with progressive distension of the abdomen, along with poor weight gain for 3 months. On examination, he had bilateral non-tender parotidomegaly (figure $1 \mathrm{~A}, \mathrm{~B}$ ), grade II clubbing (figure 2A), generalised lymphadenopathy, severe wasting and stunting, along with firm hepatomegaly. Examination of the respiratory, cardiovascular and central nervous system was unremarkable. He was found to be seropositive for HIV by ELISA. His CD4 count was $1194 / \mathrm{mm}^{3}$. Both mother and father were seropositive for HIV. A chest X-ray revealed bilateral reticular infiltrates (figure 2B). Workup for tuberculosis, cytomegalovirus and Pneumocystis jiroveci was negative. Screening for other opportunistic infections was also negative.

CT of chest revealed areas of ground glass opacities and multiple reticulonodular infiltrates, along with hilar, paratracheal and subcarinal lymphadenopathy (figure 2C).

Fine-needle aspiration from the lymph nodes was suggestive of reactive lymphoid hyperplasia. Echocardiography was not suggestive of pulmonary arterial hypertension. Serology for Epstein-Barr virus viral capsid antigen was positive. The PCR was not done.

A diagnosis of HIV infection with lymphocytic interstitial pneumonia was made, and the child was started on zidovudine, lamivudine and efavirenz. On follow-up for 3 months, there was a significant reduction in the size of the parotid gland.

Bilateral painless parotidomegaly occurs in about $10 \%$ of patients with HIV, and is usually secondary to CD8 lymphocyte infiltration and lymphoid proliferation, causing ductal obstruction and cyst
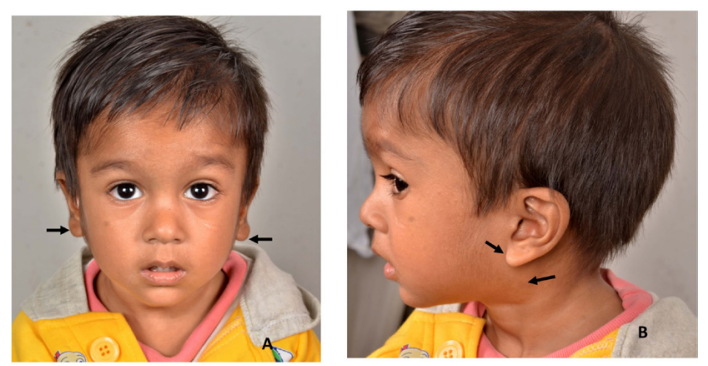

Figure 1 (A) Photograph of the face (frontal view) showing superior displacement of bilateral ear lobules due to parotidomegaly. (B) Photograph of the face (lateral view) showing parotidomegaly with a superior displacement of ear lobule.

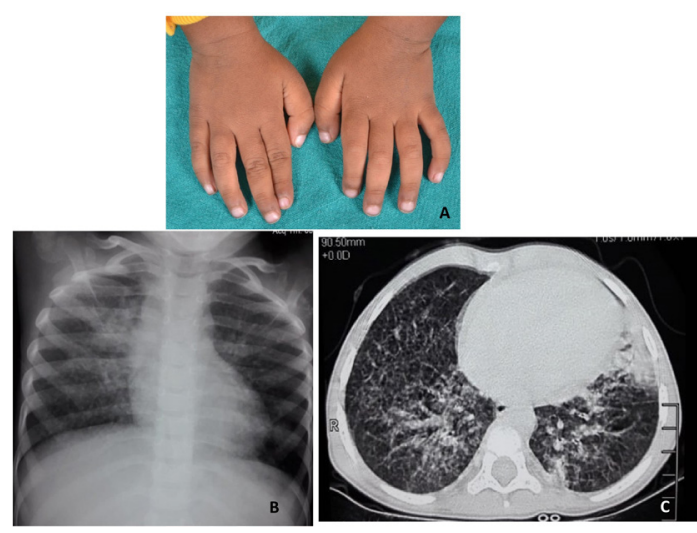

Figure 2 (A) Photograph of hands showing grade II clubbing. (B) Anteroposterior chest X-ray showing bilateral infiltrates. (C) CT chest showing bilateral reticular infiltrates with ground glass opacities.

formation. Soft tissue imaging is usually suggestive of gland enlargement with multiple cystic lesions, and aspiration cytology reveals foamy macrophages, lymphocytes and atypical squamous cells in a proteinaceous background. Management is usually conservative as most regress with antiretroviral therapy. However, close monitoring is advocated since malignant transformation needs to be ruled out. ${ }^{1}$

Lymphocytic interstitial pneumonia is the second most common disease of the respiratory system in HIV infection affecting 30\%-50\% of children, after pneumocystis pneumonia, and is recognised as an AIDS-defining condition in the paediatric population. ${ }^{2}$ It is characterised by lymphoid hyperplasia of the bronchus-associated lymphoid tissue and infiltration of the pulmonary interstitium with $\mathrm{CD} 8^{+}$ $\mathrm{T}$ lymphocytes and is usually seen with preserved CD4 counts. Children may also have generalised lymphadenopathy, hepatosplenomegaly or painless parotid enlargement secondary to the abnormal lymphoproliferative response, which may be a subtle marker of the respiratory involvement. It is usually a benign disease with 5 -year survival more than $60 \%$, however, the malignant transformation may be seen in less than $5 \%$ of patients. ${ }^{3}$

Contributors DB, NJ and PP: patient management, literature review and preparation of the initial draft of the manuscript. PV: clinician in-charge, critical review of the manuscript for important intellectual content and final approval of the version to be published. 


\section{Learning points}

Bilateral non-tender parotidomegaly is a soft pointer towards underlying HIV infection in children.

- Lymphocytic interstitial pneumonia should be considered in children with HIV infection, clubbing, parotidomegaly and well preserved CD4 lymphocyte count.

- The pathogenesis is usually attributed to the abnormal proliferation of lymphoid tissue due to HIV or Epstein-Barr virus.
Funding The authors have not declared a specific grant for this research from any funding agency in the public, commercial or not-for-profit sectors.

Competing interests None declared.

Patient consent for publication Parental/guardian consent obtained.

Provenance and peer review Not commissioned; externally peer reviewed.

\section{REFERENCES}

1 Ebrahim S, Singh B, Ramklass SS. HIV-associated salivary gland enlargement: a clinical review. SADJ 2014;69:400-3.

2 Sharland M, Gibb DM, Holland F. Respiratory morbidity from lymphocytic interstitial pneumonitis (LIP) in vertically acquired HIV infection. Arch Dis Child 1997;76:334-6.

3 Panchabhai TS, Farver C, Highland KB. Lymphocytic Interstitial Pneumonia. Clin Chest Med 2016;37:463-74.

Copyright 2019 BMJ Publishing Group. All rights reserved. For permission to reuse any of this content visit https://www.bmj.com/company/products-services/rights-and-licensing/permissions/

BMJ Case Report Fellows may re-use this article for personal use and teaching without any further permission.

Become a Fellow of BMJ Case Reports today and you can:

- Submit as many cases as you like

- Enjoy fast sympathetic peer review and rapid publication of accepted articles

- Access all the published articles

Re-use any of the published material for personal use and teaching without further permission

For information on Institutional Fellowships contact consortiasales@bmjgroup.com

Visit casereports.bmj.com for more articles like this and to become a Fellow 